\title{
Retraction Note to: Motorized Level of Service Classification for Urban Uncontrolled Intersections
}

\author{
Suprabeet Datta ${ }^{1} \cdot$ Siddhartha Rokade $^{1} \cdot$ Sarvesh P. S. Rajput ${ }^{1}$
}

Published online: 11 August 2021

๑) Springer Science+Business Media, LLC, part of Springer Nature 2021

Retraction Note to: International Journal of Intelligent Transportation Systems Research https://doi.org/10.1007/s13177-020-00238-x

The Editor-in-Chief has retracted this article because it shows significant overlap with a previously published article by the same authors [1]. The authors agree to this retraction.
Publisher's Note Springer Nature remains neutral with regard to jurisdictional claims in published maps and institutional affiliations.

\section{References}

1. Datta, S., Rokade, S. \& Rajput, S.P.S. Classification of Uncontrolled Intersections Using Hierarchical Clustering. Arab J Sci Eng 45, 8591-8606 (2020). https://doi.org/10.1007/s13369-020-04753-7

The original article can be found online at https://doi.org/10.1007/ s13177-020-00238-x.

Suprabeet Datta

sdce90@gmail.com

Siddhartha Rokade

siddhartharokade@gmail.com

Sarvesh P. S. Rajput

spsrajput@manit.ac.in

1 Department of Civil Engineering, MANIT, Bhopal, India 